\title{
Spatial and temporal variability of sediment transfer and storage in an Alpine basin (Reintal valley, Bavarian Alps, Germany)
}

\author{
Lothar Schrott, Joachim Götz, Salzburg, Martin Geil- \\ hausen, Bonn, David Morche, Halle
}

\section{Introduction}

Spatial and temporal sediment flux within alpine sediment cascading systems is still poorly understood. Specific patterns of sediment storage types in alpine environments may be interpreted to be a result of temporal and spatial interaction of geomorphic processes. Thus, they can be considered to be geomorphic process units. Major problems encountered in research in this area appear to be related to the highly variable and changing residence times of stored sediments and to different buffering capacities in alpine catchments (Caine 1986; Fryirs \& Brierley 2001; Walling 1999; Slaymaker 2003). This would seem to have a significant influence on sediment yield and hence on sediment budget (Trimble 1995, 1999; WaLling 1999).

To improve the general understanding of alpine landscape evolution, it is evident that quantitative studies of sediment storage and transfer are necessary (Schrotr \& Adams 2002). Despite the difficulties of such research at larger spatial and temporal scales, the project described herein aims firstly, at investigating spatial distribution of sediment storage types with respect to their activity and geomorphic coupling, and secondly, at quantifying valley fill deposits using a geomorphometric approach, refraction seismic and geographical information systems (GIS) techniques (SchrotT et al. 2002, 2003). The project is embedded within a larger project on sediment cascades in alpine geosystems (Sedimentkaskaden in alpinen Geosystemen - SEDAG).

Of particular interest in this research project are clastic sediment fluxes in selected geomorphic process units that show significant sediment transfer activity. The spatial and temporal patterning of active surface areas was carried out using geomorphological mapping, orthophoto interpretation, digital elevation models (DEMs) and GIS-tools. The main objectives of the project are

(i) to compare active surface areas with regard to recent sediment fluxes by field mapping and bitemporal orthophoto interpretation;

(ii) to differentiate between erosion and accumulation areas on highly active talus slopes by quantifying area and volume of present-day sediment transfer; and (iii) to assess these short term values (one to four years) with long term values of sediment stores (Late and Postglacial).

Three different spatial scales are considered in this project. Bi-temporal orthophoto interpretation was carried out for the whole mapping area, comprising all talus slopes and the entire valley floor $\left(3 \mathrm{~km}^{2}\right)$ of the sub-catchment of the Reintal $\left(17 \mathrm{~km}^{2}\right)$ (see Fig. 1). Further, a stretch of several north facing talus slopes in the middle part of the valley $\left(0.37 \mathrm{~km}^{2}\right)$ and a comparatively small talus sheet/debris cone-complex within this stretch $\left(0.05 \mathrm{~km}^{2}\right)$ were processed in more detail using field measurements and DEM-calculations with regard to debris flow activity and sediment transfer (see Fig. 2).

\section{Research area}

The catchment of the Reintal valley is located in the Wettersteinmassiv in the Bavarian Alps near the border between Germany and Austria (Fig. 1). The basin is surrounded by some of the highest summits of Germany, including Zugspitze with $2960 \mathrm{~m}$ asl. It is drained by the Partnach River, a tributary of the Loisach River.

The Reintal valley has an asymmetrical cross-profile with very steep $\left(>45^{\circ}\right)$ north-facing rock walls and more gentle, south-facing slopes. The basin has a typical through-shaped morphology due to former, particularly Pleistocene glaciation. The remnants of Lateglacial moraines to be found along the valley floor speak for this (Hirtlreiter 1992; SchrotT et al. 2002).

The geological and lithological settings are dominated by an underlying massive and partially thick bedded Triassic limestone. For this reason, karst features and partially subterranean drainage are to be found in the basin. In addition, several natural rockfall dams and slope-channel decoupling contribute towards clastic sediment output (SchmidT \& Morche 2006). Their contribution is, however, negligible.

The total drainage basin with an area of $27 \mathrm{~km}^{2}$ is alpine in character with altitudes ranging from 1050 to $2960 \mathrm{~m}$ asl. The sub-catchment considered in the SEDAG Project is $17 \mathrm{~km}^{2}$. It comprises the main valley floor, the adjacent talus slopes and the rock walls and hanging valleys above it. 


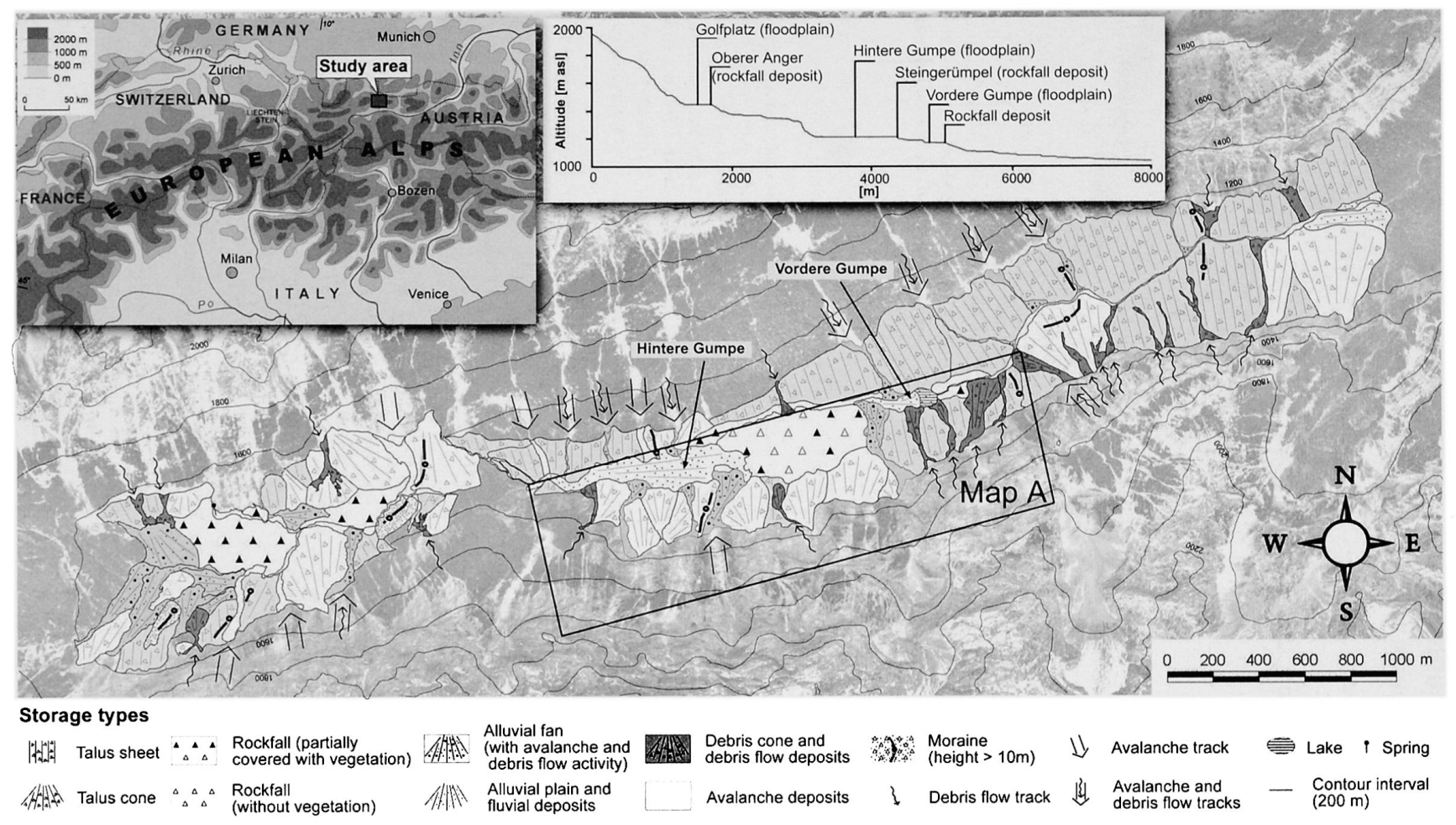

Fig. 1: Location of the study area in the northern Bavarian Alps with mapped sediment storage types, a longitudinal profile of the Reintal valley and the sector of the detailed map (Map A)

Lage des Untersuchungsgebiets in den Nördlichen Bayerischen Kalkalpen mit Sedimentspeichertypen, Längsprofil des Reintals und einem Ausschnitt der Detailkarte (Map A)

Emplacement du secteur d'étude dans le nord des Alpes bavaroises montrant différents types de dépôts de sédiments, le profil longitudinal du Reintal et une carte détaillée (Map A)

Source: Based on digital orthophotos (Bayerisches Landesvermessungsamt, München, 2003) (reprinted with permission) 


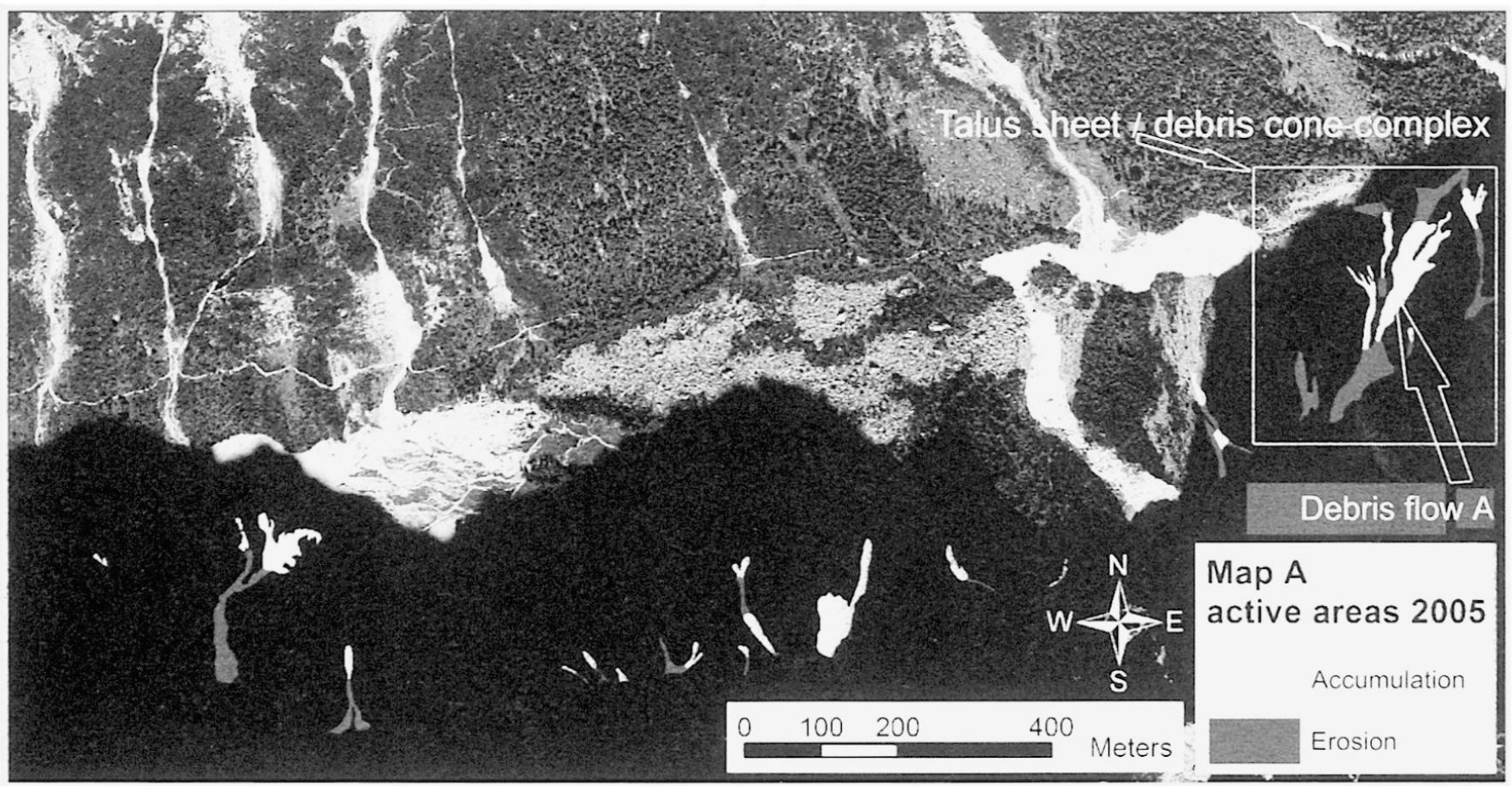

Fig. 2: Location of the sub-catchment in the central part of the Reintal valley on the north facing slopes. Active areas are marked, differentiated according to dominating processes of erosion or accumulation. On the right, the talus sheet/debris cone-complex with debris flow A is highlighted.

Lage des Subeinzugsgebiets im mittleren, nordexponierten Bereich des Reintals mit den aktiven Bereichen, differenziert nach Erosions- und Akkumulationsfächen. In der rechten Bildhälfte ist der Ausschnitt des Schutthalden/ Murkegel-Komplexes mit der rezent aktiven Übermurung A hervorgehoben.

Emplacement du sous-bassin dans la zone centrale du Reintal exposée au nord. Les secteurs actifs, différenciés selon la dominance de l'érosion ou de l'accumulation, sont indiqués. A droite, le complexe de talus d'éboulis et de cônes de laves torrentielles et le flux de débris A sont mis en évidence.

Source: Based on digital orthophotos (BAYERISCHES LandesvermesSungSamt 2003) (reprinted with permission)

The main valley floor and the talus slopes are characterized by a variety of sediment storage types (talus sheets and cones, debris cones, rockfall deposits, alluvial fans, avalanche deposits, moraines and some more complex landforms) which developed in Postglacial times. Due to natural rockfall dams, three large alluvial plains (Golfplatz, Vordere Gumpe and Hintere Gumpe) were created in the Holocene as almost closed sediment sinks (Fig.1) (Schrott et al. 2002). However, since August 2005, the sediment sink of the Vordere Gumpe no longer exists due to an extreme flash flood event (MORCHE et al.2006).

According to Chorley \& KenNedy (1971), the basin can be defined as a «sediment cascade» with three subsystems, namely rockwall (I), slope (II) and valley bottom (III). These three subsystems are more or less connected to each other through processes and influenced by regulators.

Although subsystem I extends over an area of $14 \mathrm{~km}^{2}$, thereby making up more than $82 \%$ of the sub-catch- ment, it is of minor importance with regards to sediment storage. The morphology of this system is characterized by steep rock walls, small cirques and hanging valleys with shallow developed talus slopes. In contrast, subsystems II and III are predominantly accumulation areas. They make up about $3 \mathrm{~km}^{2}$ or $18 \%$ of the total research area and include the main valley floor and adjacent talus slopes (see Fig. 1).

At present, however, many landforms and, in particular, the talus sheets and cones in the lower part of the valley are decoupled from the geomorphic system and no significant clastic sediment input, remobilisation or output appears to occur (Schrotr et al. 2002).

The investigated sub-basin in the middle of the valley is characterized by a relatively strong coupling of subsystem I and II through rockfall activity. Sediment output or transfer from subsystem II (slope) to subsystem III (valley bottom) is limited to single landforms, generally occurring during high magnitude rainfall events (Fig. 3). 


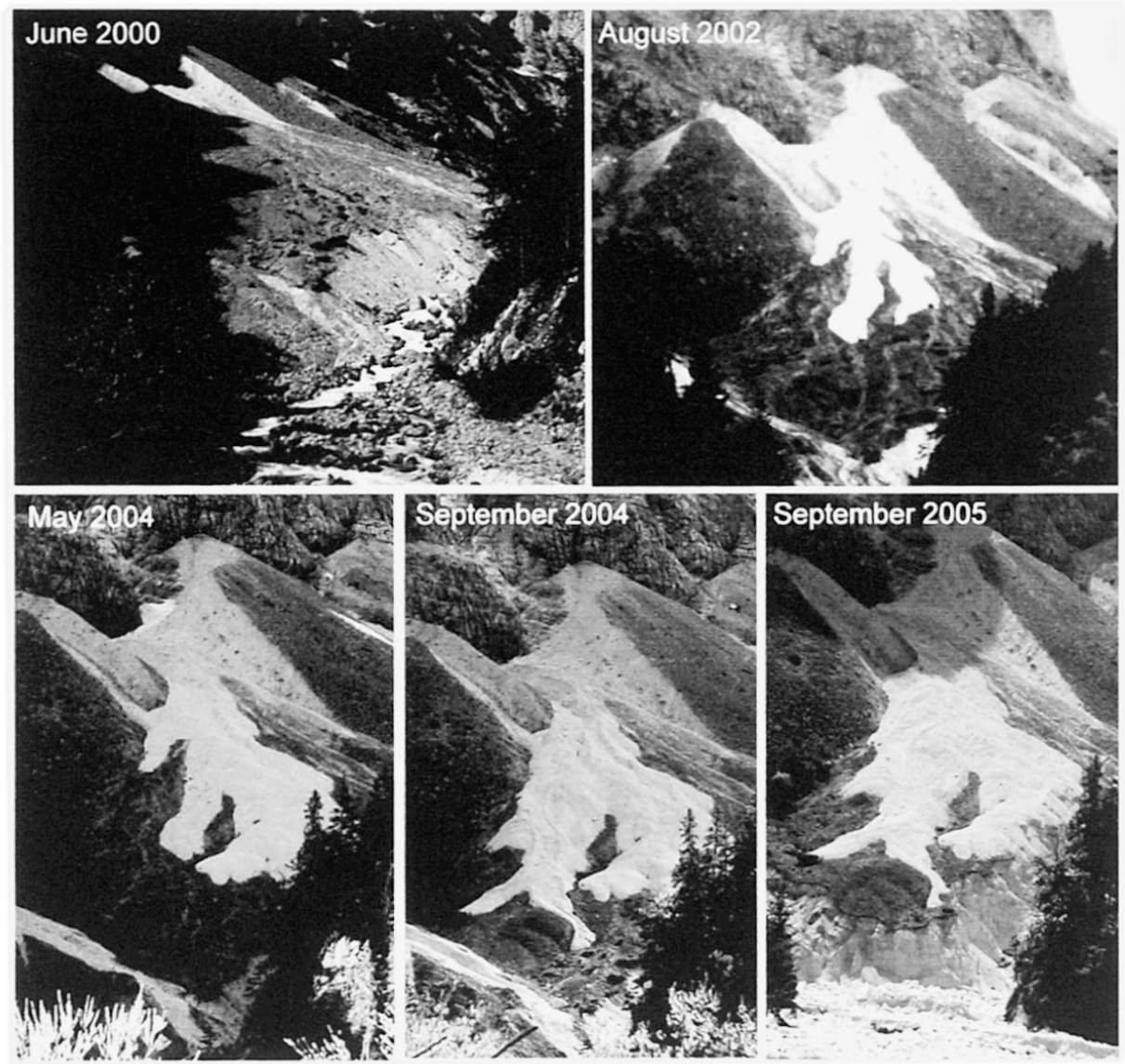

Fig. 3: Photographic sequence of the talus sheet/debris cone-complex (location see Fig. 2) Fotosequenz des Schutthalden/Murkegel-Komplexes (Lage des Komplexes vgl. Fig. 2) Séquence de photos du complexe de talus d'éboulis et de cônes de laves torrentielles (voir Fig. 2) Photos: L. SchrotT and J. GöTz

\section{Methods, techniques and modelling approaches}

\subsection{Data basis}

Spatial information of subsystems II and III draws from 126 sediment storage units determined primarily by geomorphologic mapping and field reconnaissance. To further differentiate between each sediment store, additional attributes like surface area, vegetation cover and density estimates of talus were included. Current land-use was estimated using semi-quantitative classification (Schrotr et al. 2002). Volume and mass calculations from previous research, based on a combined geophysical and geomorphometrical approach, were also included (HofFmann \& SCHrott 2002). The modelled sediment thickness and volume is taken to represent the entire input of the Lateglacial and Holocene, as natural rockfall dams seem to have hindered any significant sediment output (ScHrotr et al. 2002) (see Fig. 1).

Temporal data with regards to recent sediment transfer for the whole research area was derived from bi- temporal orthophoto interpretation (1999 and 2003) with a raster resolution of $0.4 \mathrm{~m}$.

In addition to field measurements in August 2005 and to improve the spatial and temporal information of the talus sheet/debris cone-complex, DEMs from 1960 and 1999 (LANDESVERmessungSamt Bayern, improved by the working group Prof. Kähler, Technische Fachhochschule Berlin) and a DEM from 2003 (resting on geodetic measurements) were used.

\subsection{Processing}

In this study, three different spatial scales are processed: the mapping area of $3 \mathrm{~km}^{2}$, a section of the talus slopes, and the talus sheet/debris cone-complex.

(1) Mapping area $\left(3 \mathrm{~km}^{2}\right)$ : This area was analysed by means of orthophoto interpretation. Differentiation between active and inactive surface areas within individual storage types was based on colour differences, active areas appearing brighter than weathered areas. These areas were further differentiated between loca- 


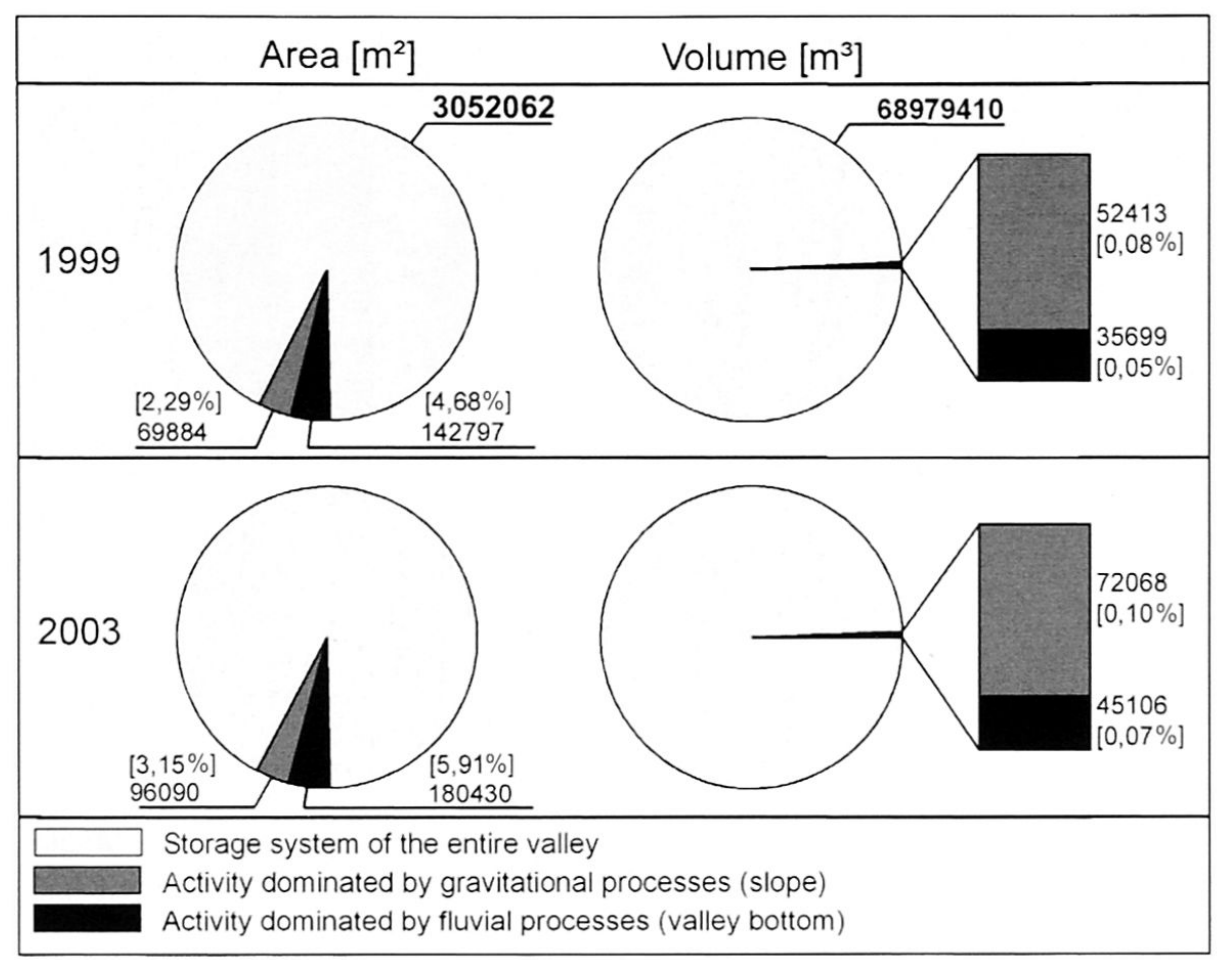

Fig. 4: Active surface areas and calculated volumes of the mapping area in 1999 and 2003 compared with the overall sediment stored in the Reintal valley

Aktive Bereiche und berechnete Volumina des Kartiergebietes aus den Jahren 1999 und 2003 im Vergleich zum Sedimentgesamtvolumen im gesamten Reintal

Secteurs actifs et les volumes calculés de la zone en question pour les années 1999 et 2003 en comparaison avec le volume total de sédiments du Reintal

tion in subsystem II (slope) or subsystem III (valley bottom) (Schrotr et al. 2002). Active surface areas were digitised as feature classes in GIS (ArcGIS editor toolbox) and structured in spatial (subsystems II and III) and temporal (1999 and 2003) classes. This resulted in four data sets («slope 1999», «slope 2003», «valley bottom 1999», «valley bottom 2003») representing together the area of active sediment transfer for the entire valley (Fig. 4). In a next step, the digitised active sub-areas were merged with sediment storage polygons in order to calculate an area-ratio of active to inactive sub-areas for each sediment storage type (Fig. 5).

For the calculation of volumes of recent clastic sediment fluxes several assumptions and simplifications were made:

(i) As areas of erosion and accumulation could not be discerned using orthophoto interpretation, the mapped surface of active sediment transfer was divided into equal areas.

(ii) The vertical extension of sediment deposited on subsystem II (talus slopes) was given an average value of $1.5 \mathrm{~m}$, that of the valley bottom in subsystem III, $0.5 \mathrm{~m}$.
In a final step, volumes of recently remobilised sediments were compared with the overall sediment stored in the valley. This allowed conclusions to be drawn about overall sediment mobilisation since the Lateglacial (Fig. 4 and 5).

(2) A stretch of talus slopes in the middle part of the valley $\left(0.37 \mathrm{~km}^{2}\right)$ : To identify recent sedimentation patterns, a detailed mapping campaign was carried out between August and September 2005 on north facing talus slopes in the central part of the catchment (see Fig. 1 and 2). The sub-basin scale was also selected as a control area in order to validate the results of the orthophoto interpretation.

At this scale, basic active debris flows on the talus sheets and cones could be surveyed in more detail. Erosion and accumulation surface areas were carefully distinguished. Once the longitudinal extent of the erosional and accumulational areas had been determined, cross-profiles in $10 \mathrm{~m}$-intervals could be carried out in the accumulation areas. Average sediment thickness was approximated by field measurements, resulting in up-to-date data on area and volume. 


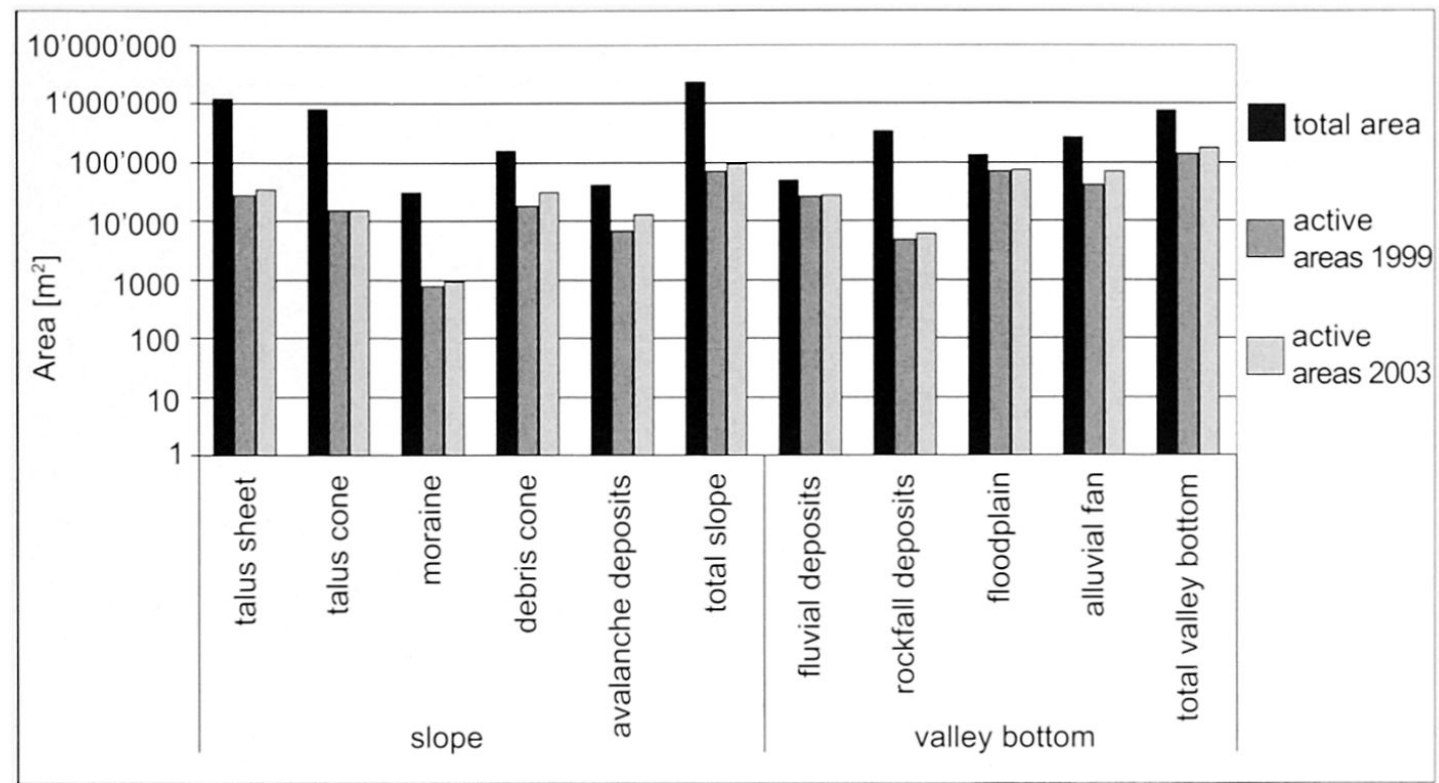

Fig. 5: Sediment transfer activity differentiated for specific storage types (1999 and 2003) in the Reintal valley Aktivität des Sedimenttransfers der verschiedenen Speichertypen (1999 und 2003) im Reintal Activité du transfert de sédiments des différents types de dépôts (1999 et 2003) dans le Reintal

The geomorphic coupling of the sediment cascade shows four general types of clastic sediment fluxes:

(a) sediment input and output occurs (sediment storage aggradation versus degradation)

(b) sediment input but no output occurs (sediment storage aggradation)

(c) sediment output but no input occurs (sediment storage degradation)

(d) neither input nor output occurs (sediment reworking).

(3) Talus sheet/debris cone-complex $\left(0.05 \mathrm{~km}^{2}\right)$ : At this level, the focus was on temporal changes of sediment transfer (Fig. 2 and 3). Orthophotos from 1999 and 2003, as well as DEMs were used for calculation of the long-term sediment transfer on the talus sheet/ debris cone-complex. Additionally, short-term sediment transfer estimation (erosion and accumulation) was made possible with data from geodetic surveys carried out in August 2003 and August 2005. The resolution of the official 1999 DEM (C) LANDESVERMESSUNGSAMT BAYERN) was improved from a $5 \mathrm{~m}$ grid to a 1-3 m grid. A 1960 DEM was generated by the working group of Prof. Dr. Ing. M. Kähler (Technische Fachhochschule Berlin, laboratory of photogrammetry) using photogrammetry techniques.

For three different years $(1960,1999,2003)$, a surface grid of the talus sheet/debris cone-complex was calculated. The changes were expressed in volume, with negative volumes indicating erosion and positive vol- umes, accumulation. These volumes were converted into masses by using a bulk density of talus sheets of $2 \mathrm{~g} \mathrm{~cm}^{-3}$.

\section{Results}

\subsection{Catchment findings}

More than $85 \%$ of the talus sheets and cones in the valley can be considered relict landforms. In terms of paraglacial notions, these landforms are decoupled from present-day geomorphic systems. Present-day activity of sediment flux is limited to approximately $9 \%$ of the valley floor and adjacent talus slopes. Notable sediment transport could only be observed along avalanche tracks. alluvial fans, debris flows and within the floodplains (Fig. 5). Activity in subsystem II (slope) is dominated by gravitational processes e.g. debris flows, whereas activity in subsystem III (valley bottom) is characterized by fluvial processes.

At catchment scale, areas with sediment transfer activity (erosion and accumulation) increased from $212.681 \mathrm{~m}^{2}$ in 1999 to $276.520 \mathrm{~m}^{2}$ in 2003 . Active surface areas thus increased in total by $15.960 \mathrm{~m}^{2} \mathrm{a}^{-1}$.

As mentioned above, vertical extensions of «active volumes" were estimated to be $88.112 \mathrm{~m}^{3}$ in 1999 and $117.174 \mathrm{~m}^{3}$ in 2003, thus indicating a possible increase of $29.062 \mathrm{~m}^{3}$ within four years, or $7266 \mathrm{~m}^{3}$ per year. The recent volumes transferred by sediment fluxes corre- 
spond to $0.17 \%$ of the total volume of sediment in the catchment $\left(\sim 0.07 \mathrm{~km}^{3}\right)$. The estimated volumes, however, include both remobilisation and sediment input.

Assuming sediment aggradation took place solely in Postglacial times and that after deglaciation, there was an almost «empty basin», the total sediment volume would require a Lateglacial and Holocene (approximately 12.000 years) linear sedimentation rate of $5.833 \mathrm{~m}^{3} / \mathrm{a}$, which is considered here to be unrealistic.

\subsection{Sub-catchment findings}

As noted above, in summer 2005 a detailed mapping campaign was carried out on the north facing talus slopes (subsystem II) in the central part of the valley. The area of the sub-basin extends over $366.600 \mathrm{~m}^{2}$, corresponding to $12 \%$ of the mapping area. Sediment transfer is strongly controlled by a total of 19 debris flows (Fig. 2).

In most cases, these active debris flows were decoupled from the sediment cascade, resulting in scarp, pathway and accumulation area being located within subsystem II (slope) (Fig. 2). However, sediment input from subsystem I (rockwall) occurs more frequently than sediment output into the Partnach creek, output being limited to extreme rainfall events with intense slope-channel interaction (Fig. 3 and 6) (KRAutblatter 2004; Krautblatter \& Moser 2005).

The total accumulation area of the sub-catchment according to field measurements amounts to $11.861 \mathrm{~m}^{2}$. The transfer of digital datasets 1999 and 2003 to the area of the sub-catchment indicate active accumulation areas of $8.070 \mathrm{~m}^{2}$ (1999) and $12.175 \mathrm{~m}^{2}$ (2003), respectively. Although the values of the measured and digitised sediment transfer analysis are not directly comparable because they represent different time scales $(2005,2003$, and 1999), the orthophoto interpretation provides relatively accurate values.

By multiplying the measured areas of accumulation $\left(11.861 \mathrm{~m}^{2}\right)$ with the approximated vertical extends (minimum value: $30 \mathrm{~cm}$, maximum value: $2 \mathrm{~m}$ ), the total volume of the accumulation areas can be estimated to be $14.734 \mathrm{~m}^{3}$.

\subsection{Talus sheet/debris cone-complex findings}

This area is a highly active landform complex. The debris cone located within a larger talus sheet complex showed until 2002 only moderate erosion and accumulation activity. An extreme rainfall event on June 14, 2003 triggered a debris flow (debris flow A), leaving fresh and large deposits on the older debris cone (Fig. 3). This event was accompanied by a sediment input of 220 tons through rockfalls (KRAUTBLaTTER 2006). A geodetic survey carried out in 2003 indicated an accumulated volume of 6.960 tons, under the assumption of a bulk density of $2 \mathrm{~g} \mathrm{~cm}^{-3}$. After another extreme rainfall event in summer 2004, measurements taken in August 2005 indicated an accumulated mass of 15.498 tons (Fig. 3). During a high magnitude flood event on August 23,2005, the River Partnach heavily truncated debris flow A at the distal part of the talus sheet, resulting in a reduced mass of 13.574 tons. Interestingly, this last event led to neither sediment input from subsystem I (rockwall) into subsystem II (slope), nor to any sediment remobilisation within subsystem II. This could be due to a reduced sediment availability and/or resistance in the source areas of the cascading system and upper parts of the talus. Fig. 3 illustrates the development of debris flow $\mathrm{A}$ in a sequence of photographs from 2002 to 2005.

\section{Discussion}

Based on the idea formulated by Ballantyne (2002) that different paraglacial subsystems relax over different timescales, several assumptions regarding Postglacial landform development in the Reintal catchment are discussed below. It seems obvious that currently, some paraglacial sediment storages are experience net erosion while others continue to accumulate. In the research area, both types are found side by side. Two examples are shown in Fig. 6.

Basically, the application of the general steady-state model of paraglacial sediment storage requires four parameters, namely (i) the time elapsed since deglaciation, (ii) the present volume of stored sediment, (iii) the maximum volume of stored sediment and (iv) the time when maximum volume was achieved. In principle, the model implies that there is an intrinsic change from net accumulation to net erosion for all paraglacial sediment stores at a time when maximum volume of storage was achieved unless sediment loss is zero (BALlantyne 2003).

For the talus sheet/debris cone-complex recently degradated by debris flow $\mathrm{A}$ and river undercutting, the first and second parameter can be adequately estimated with 12.000 years and 1.01 million $\mathrm{m}^{3}$, respectively. However, maximum volume of stored sediment and time of maximum volume remains speculative and is far more difficult to determine.

Geodetic field measurements and calculations using DEMs of 1960 and 1999 indicate that the accumulation of sediment is stronger than actual erosion between 1960 and 1999, resulting in a total positive sediment budget of $5.125 \mathrm{~m}^{3}$. In contrast, the period between 1999 and 2003 is characterized by a negative sediment budget of $5.254 \mathrm{~m}^{3}$, with erosion overriding accumulation. 

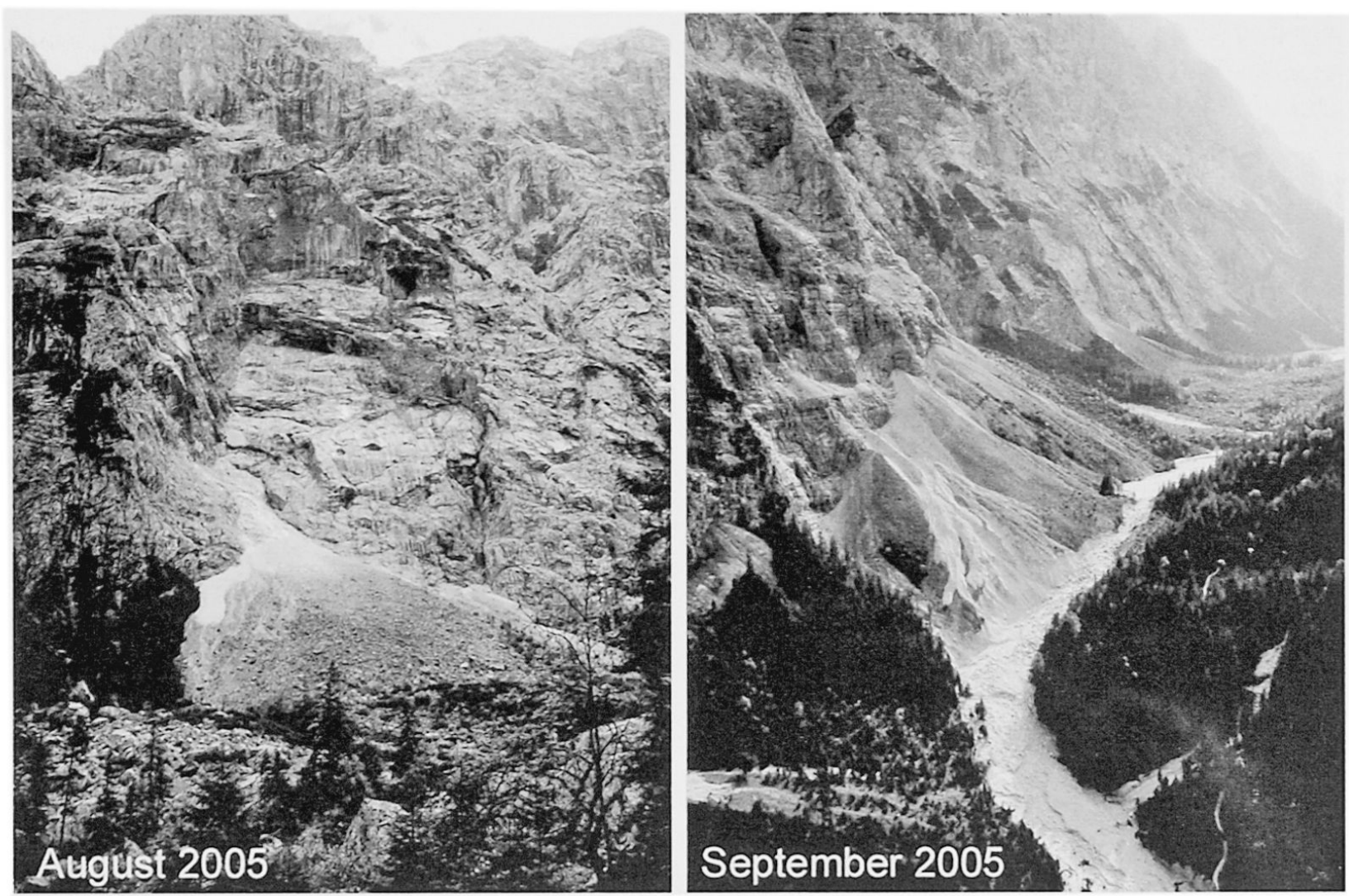

Fig. 6: Aggradating paraglacial sediment store (talus cone, left) versus degradating paraglacial sediment store (talus sheet, right) in the sub-catchment of the Reintal valley

Ein im Aufbau befindlicher paraglazialer Sedimentspeicher (Schuttkegel, links) gegeniiber einem im Abbau befindlichen paraglazialen Sedimentspeicher (Schutthalde, rechts) im Einzugsgebiet des Reintals

Dépôt de sédiments paraglaciaires en formation (cône d'éboulis, à gauche) et en voie de disparition (talus d'éboulis, à droite) dans le sous-bassin du Reintal

Photos: L. Schrotr (left), D. Morche (right)

On the basis of the negative budget since 1999, it could be assumed that maximum volume was achieved on the talus sheet/debris cone-complex around 1999. However, it is possible that this value does not reflect the paraglacial maximum. The existence of a large debris cone superimposed on a talus sheet can be an indication of previous stages with higher sediment storage values on this talus slope.

Thus, it is questionable whether paraglacial sediment stores have to aggradate to one single maximum, before degradation dominates. Aggradation of talus sheets and cones in the Reintal catchment seems to be strongly affected by the sediment availability in subsystem I, leading to secondary rockfall events. This is supported by the fact that the extreme rainfall event in June 2003 was followed by increased sediment input of 220 tons, whereas the event in August 2005, with a similar (or even higher) precipitation magnitude, did not lead to any sediment input.
BECHT et al. (2005) used field measurements to estimate the accumulated mass of a debris flow on the talus sheet/debris cone-complex after the 2003 event by assuming a simple planar subsurface structure. Their results (5.530 tons) are, as a consequence, lower than those published herein (namely 6.960 tons).

\section{Conclusions}

This study has shown the high spatio-temporal variability of sediment transfer in an Alpine catchment. Results with regard to sediment transfer activity patterns and rainfall trigger events exemplify the difficulty of getting reliable data on clastic sediment fluxes and in turn on rates of denudation. This supports arguments emphasising the strongly inhomogeneous patterns of mechanical denudation in mountain areas (CAINE 2005). More general conclu- 
sions that can be drawn from this study are as follows:

- At all scales investigated, sediment transfer between 1999 and 2003 in the basin increased.

- Compared to remobilisation, sediment input through rockfalls was significantly lower. This is inferred on the basis of current sediment transfer values being unsuitable for long-term averages. The approximated volume of recent sediment transfer $\left(117.174 \mathrm{~m}^{3}\right)$ would lead - if taken as sediment input - to extremely high and unrealistic sedimentation rates. In such a scenario, the entire valley fill would be attained within less than 600 years. Thus, it is assumed that recent sediment transfer is mainly characterised by remobilisation, partly showing talus slope degradation.

- In the control area, the orthophoto interpretation led to reliable results regarding active surfaces of sediment transfer. More accurate and intense field measurements are necessary for calculations of vertical extension and sediment volume.

- Although the main part of talus sheets and cones in the valley is currently inactive, significant sediment transfer can be observed on single landforms. On the highly active talus sheet/debris cone-complex, a single rockfall event led to sediment input of $110 \mathrm{~m}^{3}$, accompanied however, by sediment remobilisation of $6270 \mathrm{~m}^{3}$ (BECHT et al. 2005). Consequently, the ratio of input to remobilisation was in this case 1:57.

\section{Acknowledgements}

This research was supported by a grant from the Deutsche Forschungsgemeinschaft (DFG, Schr648/1-3). The authors wish to thank M. Krautblatter, Bonn, for data on rockfalls, S. Fuchs, Halle, and the SEDAG team for general assistance in the field.

\section{References}

Ballantyne, C.K. (2002): Paraglacial geomorphology. - In: Quaternary science reviews 21: 1935- 2017.

BALLANTYNE, C.K.(2003): Paraglacial landform succession and sediment storage in deglaciated mountain valleys. Theory and approaches to calibration. - In: Zeitschrift für Geomorphologie, Supplementband 132: 1-18.

Becht, M., Haas, F., Heckmann, T. \& V. Wichmann (2005): Investigating sediment cascades using field measurements and spatial modelling. - In: IAHS Publication 291 (Sediment Budgets I; Proceedings of Symposium S1 held during the Seventh IAHS Scientific Assembly at Foz do Iguacu, Brazil, April 2005): 206-213.

CAINE, N. (1986): Sediment movement and storage on alpine slopes in the Colorado Rocky Mountains. - In: Abrahams, A.D. (ed.): Hillslope processes. - London: Allan and Unwin: 115-137.
Caine, N. (2004): Mechanical and chemical denudation in mountain systems. - In: OWENS, P.N. \& O. SLAYMAKER (eds): Mountain geomorphology. - London: Arnold: $132-152$.

Chorley, R.J. \& B.A. Kennedy (1971): Physical geography. A systems approach. - London: Prentice-Hall International.

FrYiRs, K. \& G.J. Brierley (2001): Variability in sediment delivery and storage along river courses in Bega catchment, NSW, Australia. Implications for geomorphic river recovery. - In: Geomorphology 38, 3-4: 237 265.

Hirtlreiter, G. (1992): Spät- und postglaziale Gletscherschwankungen im Wettersteingebirge und seiner Umgebung. $-=$ Münchener geographische Abhandlungen, Reihe B, 15 .

Hoffmann, T. \& L. Schrott (2002): Modelling sediment thickness and rockwall retreat in an Alpine valley using 2D-seismic refraction (Reintal, Bavarian Alps). - In: Zeitschrift für Geomorphologie, Supplementband 127: 153-173.

Krautblatter, M. (2004): The impact of rainfall intensity and other external factors on primary and secondary rockfall (Reintal, Bavarian Alps). - Magister thesis, Department of Geology, University of Erlangen-Nuremberg, Erlangen, Germany.

Krautblatter, M. \& M. Moser (2005): Die Implikationen einer vierjährigen quantitativen Steinschlagmessung für Gefahrenabschätzung, Risikoverminderung und die Ausgestaltung von Schutzmaßnahmen. - In: Proceedings of the $15^{\text {th }}$ Conference on Engineering Geology, Erlangen, April $6^{\text {th }}$ to $9^{\text {th }}: 67-72$.

Krautblatter, M. (2006): Personal communication, 17.4.2006, Department of Geography, University of Bonn.

Morche, D., Katterfeld, C., Fuchs, S. \& K.-H. SCHMIDT (2006): The life-span of a small high mountain lake, the Vordere Blaue Gumpe in the Upper Bavaria, Germany. - In: Rowan, J., Duck, R.W. \& A. WerritTY (eds): Sediment dynamics and the hydromorphology of fluvial systems. IAHS Publication 306, Wallingford: IAHS Press: 72-81.

SChmidt, K.-H. \& D. Morche (2006): Sediment output and effective discharge in two small high mountain catchments in the Bavarian Alps, Germany. - In: Geomorphology 80: 131-145.

Schrott, L., Hufschmidt, G., Hankammer, M., Hoffmann, T. \& R. Dikau (2003): Spatial distribution of sediment storage types and quantification of valley fill deposits in an alpine basin, Reintal, Bavarian Alps, Germany. - In: Geomorphology 55: 45-63.

SCHRotT, L. \& T. AdAms (2002): Quantifying sediment storage and Holocene denudation in an Alpine basin, Dolomites, Italy. - In: Zeitschrift für Geomorphologie, Supplementband 128: 129-145.

Schrott, L., Niederheide, A., Hankammer, M., HufschmidT, G. \& R. DiKau (2002): Sediment storage in a 
mountain catchment: geomorphic coupling and temporal variability. - In: Zeitschrift für Geomorphologie, Supplementband 127: 175-196.

SlaYMAKER, O. (2003): The sediment budget as conceptual framework and management tool. - In: Hydrobiologia 494: 71-82.

Trimble, S.W.(1995): Catchment sediment budgets and change. - In: Gurnell, A. \& G. Petts (eds): Changing river channels. - London: Wiley: 201-215.

Trimble, S.W. (1999): Decreased rates of alluvial sediment storage in the Coon Creek Basin, Wisconsin, 1975-1993. - In: Science 285: 1244-1246.

WALLING, D.E. (1999): Linking land use, erosion and sediment yields in river basins. - Hydrobiologia 410: 223-240.

\section{Summary: Spatial and temporal variability of sediment transfer and storage in an Alpine basin (Reintal valley, Bavarian Alps, Germany)}

This paper focuses in particular on clastic sediment fluxes on talus slopes. Using orthophoto interpretation, field measurements and GIS-techniques, a quantification of areas and volumes of active sediment transfer related to specific landform units was achieved for different spatial scales. Closer investigation of a single landform complex, more specifically a talus sheet/ debris cone-complex, brought to light that remobilisation can overbalance sediment input by a factor of 57 . This could be an indication of what may be expected in the whole catchment. At present, approximately $9 \%$ of the research area $\left(3 \mathrm{~km}^{2}\right)$, comprising talus slopes and valley bottom, is characterised by sediment transfer mainly through gravitational and fluvial processes. A comparison of the vast volumes $\left(117.174 \mathrm{~m}^{3}\right)$ derived from these active areas of recent sediment transfer and the volume of the entire valley fill $\left(0.07 \mathrm{~km}^{3}\right)$ indicates, however, that the largest part must be related to remobilised sediments and cannot be considered as sediment input from the adjacent rockwalls. This conclusion is also supported by direct measurements of sediment input.

\section{Zusammenfassung: Raum-zeitliche Variabilität des Sedimenttransfers und der Sedimentspeicherung in einem alpinen Einzugsgebiet (Reintal, Bayerische Alpen, Deutschland)}

Dieser Aufsatz beschäftigt sich mit Sedimenteinträgen und -umlagerungen auf alpinen Schutthängen. Auf der Grundlage von Orthophotos, Kartierungen (Vermessungen) und GIS-Techniken wurden Flächen und Volumina des Sedimenttransfers in unterschiedlichen räumlichen Skalen quantifiziert. An einem «Schutthalden/Murkegel-Komplex» konnte gezeigt werden, dass gegenwärtig die Sedimentremobilisierung den Sedimenteintrag um den Faktor 57 übertrifft. In ähnlicher Weise trifft dies auch für das gesamte Einzugsgebiet zu. Derzeit sind ca. $9 \%$ der kartierten Fläche $\left(3 \mathrm{~km}^{2}\right)$ - die Hänge und der Talboden - durch aktiven Sedimenttransfer gekennzeichnet, der hauptsächlich auf gravitative und fluviale Prozesse zurückzuführen ist. Aus diesen Flächen können beträchtliche Volumina $\left(117.174 \mathrm{~m}^{3}\right)$ abgeleitet und in Beziehung zum ermittelten Gesamtvolumen des Tales $\left(0.07 \mathrm{~km}^{3}\right)$ gesetzt werden. Dieses Verhältnis weist jedoch auf einen sehr hohen Anteil an Remobilisierung hin und kann nicht über den Sedimenteintrag erklärt werden. Dies belegen auch Messungen zum direkten Sedimenteintrag.

Résumé: Variabilité spatiale et temporelle du transfert et du stockage sédimentaires dans un bassin des Alpes bavaroises (Reintal, Allemagne)

Cet article traite des flux de sédiments sur les talus d'éboulis. A l'aide d'orthophotos, de mesures de terrain et de techniques SIG, plusieurs secteurs et volumes de transfert de sédiments ont été quantifiés à différentes échelles géographiques. L'étude d'un complexe de talus d'éboulis et de cônes de laves torrentielles a permis de démontrer que la remobilisation surpasse l'apport actuel de sédiments d'un facteur de 57. D'une manière semblable, ceci est valable pour tout le bassin. Actuellement, près de $9 \%$ de ce secteur $\left(3 \mathrm{~km}^{2}\right)$ - comprenant les talus d'éboulis et le fond de la vallée - sont caractérisés par un transfert de sédiments actif, principalement dû aux processus fluviaux et gravitaires. Des volumes considérables de sédiments $\left(117^{\prime} 174 \mathrm{~m}^{3}\right)$ sont issus de ces secteurs, cependant le volume total de remplissage de la vallée $\left(0,07 \mathrm{~km}^{3}\right)$ indique une grande part de remobilisation et ne peut pas être expliqué par l'apport de sédiments. Cette conclusion est aussi confirmée par différentes mesures relatives à l'apport direct de sédiments.

Prof. Dr. Lothar Schrott, Dipl.-Geogr. Joachim Götz, Department of Geography and Geology, University of Salzburg, Hellbrunnerstrasse 34, A-5020 Salzburg, Austria.

e-mail: lothar.schrott@sbg.ac.at

e-mail: joachim.goetz@sbg.ac.at

Martin Geilhausen, Department of Geography, University of Bonn, Meckenheimer Allee 166, D-53115 Bonn, Germany.

e-mail: martingeilhausen@hotmail.com

Dipl.-Geogr. David Morche, Department of Geography, University of Halle-Wittenberg, Von-Seckendorff-Platz 3-4, D-06099 Halle, Germany.

e-mail: david.morche@geo.uni-halle.de

\section{Manuskripteingang/received/manuscrit entré le 30.1.2006}

Annahme zum Druck/accepted for publication/accepté pour l'impression: 15.9.2006 